\title{
THE EFFECT OF DIGESTION TEMPERATURE AND THE ORGANIC WASTE TYPE ON THE BIOGAS PRODUCTION
}

\author{
A. R. El-Ghalban, M. A. Abd El-Baky and H. F. Rashad \\ Mechanical Power Engineering Department, Faculty of Engineering \\ Menoufiya University, Shebin El-Kom, Egypt
}

\begin{abstract}
An experimental investigation has been carried out to study the effect of the digestion temperature and the type of organic waste on the biogas production. The experimental work is performed by using three similar lab-scale batch-fed 240 liter biogas reactors. Each of the bioreactors is designed to operate under thermophilic $\left(55 \pm 2{ }^{\circ} \mathrm{C}\right)$, mesophilic $\left(40 \pm 2{ }^{\circ} \mathrm{C}\right)$ and ambient digestion modes during the same retention time of 31 days. Three experimental test runs have been carried out on three different mixtures of organic wastes including pure cattle manure, cattle manure mixed with rice straw and cattle manure mixed with hen manure. Daily measurements are recorded for the generated biogas volumes, $\mathrm{pH}$ values, average gas pressure and the ambient temperature during each test run. The results indicate that, total biogas yield in thermophilic mode gives an increase over mesophilic mode by $4 \%, 6.5 \%$ and $80 \%$ for the first, the second and the third run, respectively. Also, the total biogas production for ambient mode is lower than thermophilic mode by $72 \%, 80 \%$ and $60 \%$ for the first, second and third run, respectively. The maximum daily biogas yield was obtained at $\mathrm{pH}$ values in the range of $(8.1-8.51)$ and $(7.11-8.24)$ for thermophilic and both of mesophilic and ambient modes, respectively. In addition, it was observed that the maximum biogas yield has been achieved at a value of $9.4 \%$ of total solid content in the slurry.

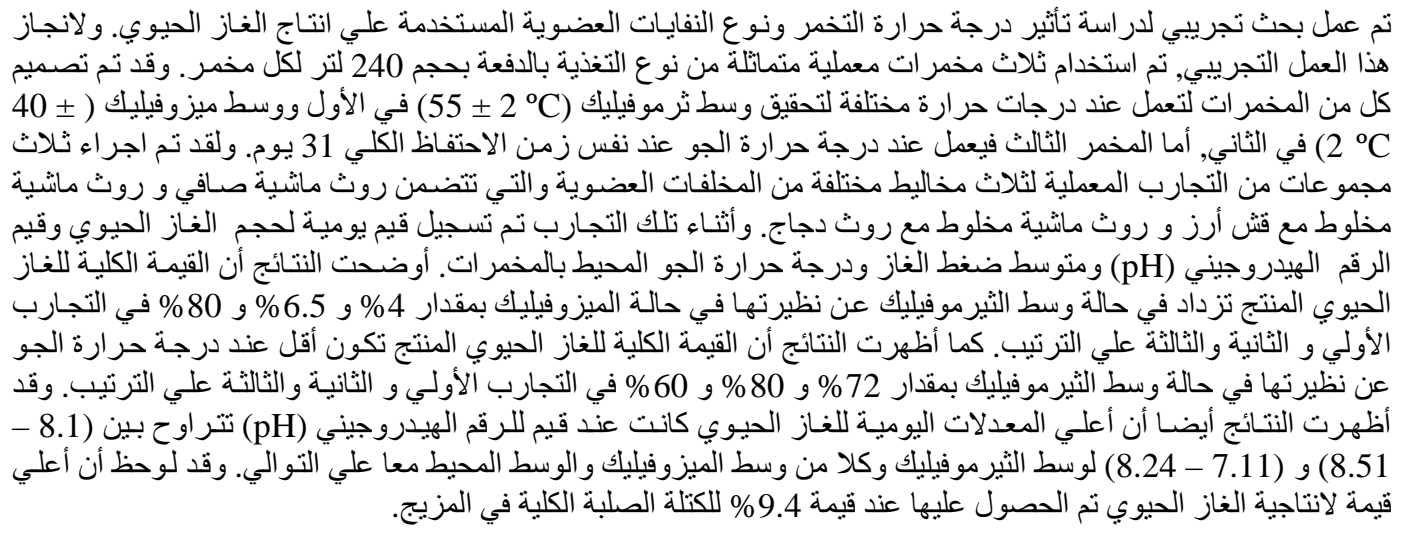

Keywords: biogas, anaerobic digestion, thermophilic mode, mesophilic mode, cattle manure, hen

\section{INTRODUCTION}

Undoubtedly, recycling the wastes becomes the most promising industries in the world and have a greater share of industrial investments of up to $28 \%$ in the United States of America, 23\% in England and 35\% in Germany, while it is found that this kind of investment is almost non-existent in the Arabic countries and limited to a modest individual attempts which in total don't exceed 150 million dollar, mostly in Egypt [1]. The lack of attention of waste recycling lost the opportunity to obtain large quantities of paper, plastics, iron and organic fertilizers that could provide billions of dollars which paid to import these products. The process of biogas generation from crop residues, animal droppings and human wastes has attracted the interest of the Egyptian scientists because of the numerous benefits realized from it. Biogas technology provides a clean and convenient fuel for cooking, lighting and generation of electricity [2].

Many researchers studied the influence of different factors on the biogas production process in order to 
optimize its yield. Sarapatka [3], Kalia and Kanwar [4] as well as Kalia and Singh [5] concluded that, the ambient temperature has a controlling effect on all performance parameters, such as biogas quantity and methane percentage. They stated that these parameters can be enhanced by the increase of the ambient temperature to about $35^{\circ} \mathrm{C}$. Cecchi et al. [6] conducted an experimental work under mesophilic and thermophilic conditions. Their results showed that the semi-dry thermophilic process (about 20\% TS feed), for retention times greater than 11 days assures $100 \%$ higher methane production with respect to the mesophilic conditions, and for retention time up to 8 days the methane production became 200\% higher in thermophilic conditions. Hammad et al. [7] designed and constructed an experimental setup to produce biogas by using four different animals manure and two different plant wastes under ambient conditions (temperature range [16- $\left.\left.44^{\circ} \mathrm{C}\right]\right)$. The results showed that both the biogas quantity and methane percentage increased as the ambient temperature was kept at the optimum temperature of about $35{ }^{\circ} \mathrm{C}$. Hejnfelt and Angelidaki [8] accomplished an experimental investigation to study the anaerobic digestion of pig's by-products in batch and semi-continuously fed reactors under thermophilic and mesophilic temperatures. They indicated that mesophilic temperatures are preferable for digestion of animal by-products, while thermophilic digestion resulted in lower yields due to higher ammonia. Al-Masri [9] studied the biogas production for eight experimental groups of fermentation media containing different ratios of animal wastes (sheeps and goats faeces) to olive cake. The results suggested that the gas production decreased significantly with increasing the amount of olive cake in the fermentation media containing either sheeps or goats wastes. Uzodinma et al. [10] conducted an experimental investigation to reveal the effect of adding some organic wastes such as palm oil sludge, soybean cake waste, powdered rice husk and pig dung to carbonated soft drink sludge on the biogas yield. The results of this research indicated that, the low yield of flammable biogas from carbonated soft drink sludge could be enhanced significantly when blended with either soybean cake waste or pig dung. Uzodinma et al. [11] presented an experimental investigation to study the biogas production rate from equal blending of field grass (F$\mathrm{G})$ with some animal wastes, which include cow dung (G-C), poultry dung (G-P), swine dung (G-S) and rabbit dung (G-R). The results of reference [11] showed fastest onset of gas flammability from the (G-R) followed by the (G-C) blends, while the highest average volume of gas production from (G$\mathrm{R}$ ) blend was 3 times higher than that of (F-G) alone. Lastella et al. [12] carried out an experimental investigation to evaluate the effects of using different bacteria inoculums on the anaerobic digestion (AD) process for orthofruit waste where the results showed that recycling of digested sludge improves both the biogas production and its methane content.

The purpose of this paper is to present the effect of the operating temperature and the type of organic waste on the biogas production for lab-scale anaerobic digesters.

\section{EXPERIMENTAL SET-UP AND PROCEDURE}

\subsection{Experimental Set-Up}

The experimental work for this study has been performed using laboratory scale set-up manufactured and assembled at the department of Mechanical Power Engineering, Faculty of Engineering, Menoufiya University at Shebin ElKom, Egypt. The set-up comprises three similar biogas production units. Each unit consists of a wood chamber containing the anaerobic batch-fed biogas digester, gas collecting and metering units and piping system to transfer the gas from the digester to the collecting units. The details of the experimental biogas production unit are given in Fig (1). As shown in this figure, the barrel formed digester with 240 liter volume is equipped with the necessary openings and valves for feeding, drainage and slurry sampling.

The new feature in the design of the digesters is the use of three internal vertical metal rods extended along the digester and fixed at its top. These rods have two functions. The first one is to collect the methanogenic bacteria responsible for activating the process of biogas production. The second function of these rods is breaking the scum layer when shaking the digester. The gas collecting and metering units consist of an approximately 150 liter rubber tiretubes connected parallel with floating cap collecting tanks of 120 liter maximum volume. The piping system is plastic hoses with suitable valves and connectors to transfer the produced gas from the digester to the gas collecting and metering unit. As mentioned above each digester is installed in thermally insulated $(1 \times 1 \times 1.5) \mathrm{m}$ wood chamber. The chamber is equipped with 1000 -Watt electric heaters, analog thermostat to achieve the desired temperature. The chamber temperature is measured with a mercury thermometer; meanwhile the gas pressure is measured with a U-tube manometer.

The digester temperature control system is used to enable conducting experiments under different digestion modes during the same retention time. The first digester is kept under thermophilic condition (55 $\pm 2{ }^{\circ} \mathrm{C}$ ), the second is kept under mesophilic condition $\left(40 \pm 2{ }^{\circ} \mathrm{C}\right)$ while the third operates under the ambient condition. 


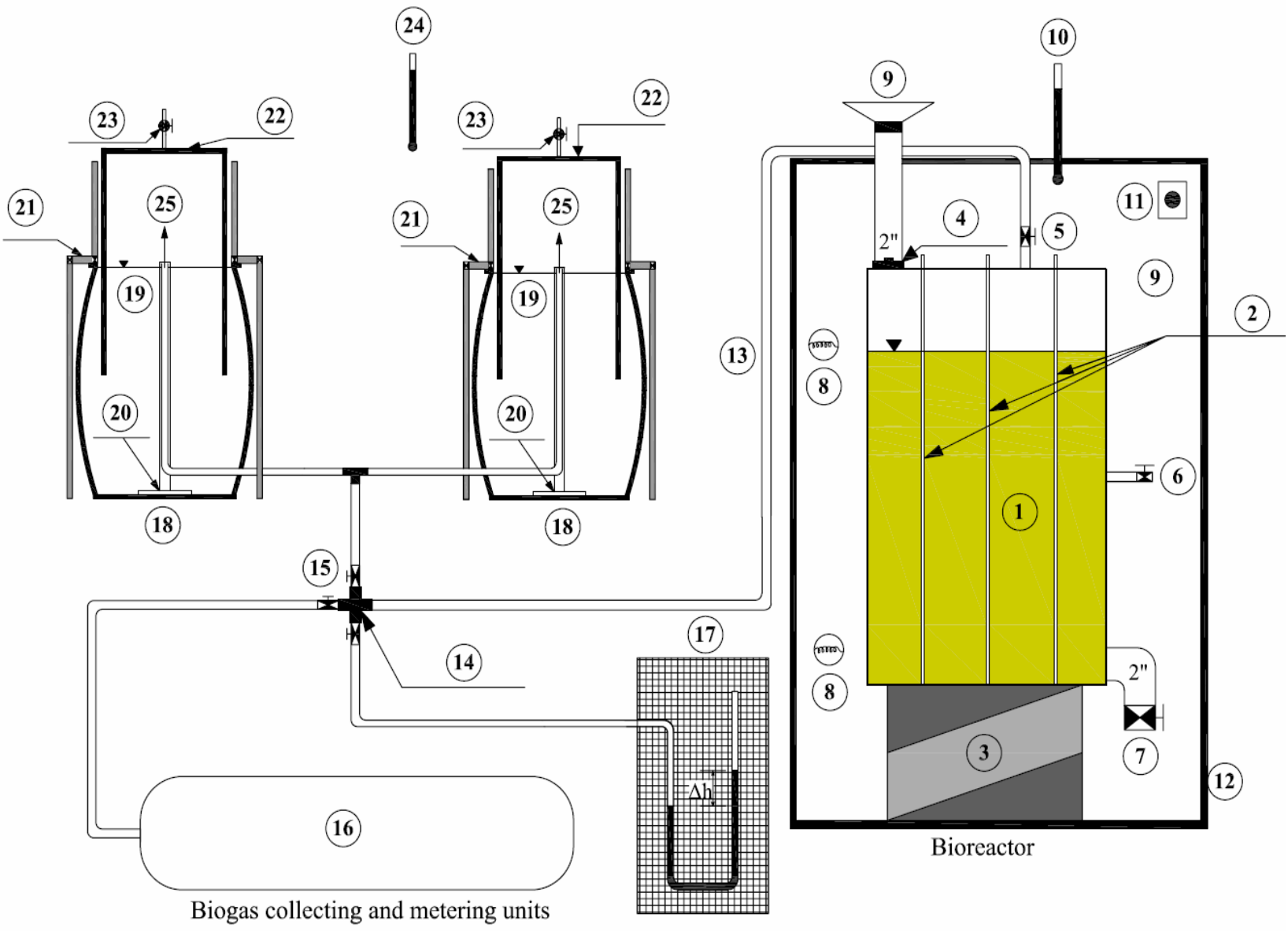

1. Organic wastes

2. Three metal rods

3. Base

4. Manhole for input slurry

5. Gas valve $\left(1 / 2^{\prime \prime}\right)$

6. Slurry sampling valve(1/2")

7. Drainage valve

8. Heater

9. Plastic funnel

\author{
10. Thermometer $\left(\mathrm{T}_{\mathrm{op}}\right)$ \\ 11. Thermostat \\ 12. Wood chamber \\ 13. Plastic hose \\ 14. Four way junction \\ 15. Gas valves (1/2") \\ 16. Rubber tire-tube \\ 17. U-tube manometer \\ 18. Expansion tank (120 L)
}

\author{
19. Water \\ 20. Vertical support \\ 21. Strong frame to guide the \\ floating tank \\ 22. Graduated collecting floating \\ tank of $60 \mathrm{~L}$ (tot. vol.) \\ 23. Gas valve (1/4") \\ 24. Thermometer $\left(\mathrm{T}_{\mathrm{amb}}\right)$ \\ 25. The biogas exit
}

Fig.1 The general arrangement of the layout of one of the biogas reactors

Experiments have been done on three types of organic wastes. The used waste types are pure cattle manure, cattle manure mixed with rice straw and cattle manure blended with hen manure. The bacteria required for acid formation and methane fermentation are present in the fresh animal manure but with low numbers. Therefore artificial seeding with the digested sludge rich in methanogenic bacteria is essential for fast activation of the anaerobic digestion process [19]. For this reason, about $10 \%$ of the digester charge for each test run was taken from the previous test run which is called digested sludge (inoculums).
After achieving the operating conditions, the digesters are fed with the prepared slurries and then the inlet openings are tightly closed to prevent gas leak.

\subsection{Instruments and Measuring Devices}

The following tools and measuring devices were used 1- U-tube manometers for each bioreactor for measuring gas pressure in the expansion tanks.

2- $100 \mathrm{~kg}$ balance (of deviation \pm 100 gram) was used for weighting organic waste samples.

3- $7 \mathrm{~kg}$ electronic balance (of deviation \pm 0.5 gram) was used to weigh the sample of slurry withdrawn from the digesters. 
4- Pocket-sized $\mathrm{pH}$ meter (HI98103 checker, \pm 0.1 $\mathrm{pH}$ of deviation) for measuring slurry acidity.

5- Seven plastic barrels (60 liters) for preparing and mixing wastes.

6- Compressor of ( $245 \mathrm{~W}$ ) to withdraw biogas from the collecting units and pressurize it into a 100 liter gas cylinder to store biogas.

\subsection{Experimental Measurements}

The daily measured and recorded parameters are; the volume of the produced gas, the gas pressure, the ambient temperature, $\mathrm{pH}$ value and total solid content (TS \%).

\subsection{Experimental Test Runs}

Three test-runs were carried out on the waste combinations given in table (1) for 31 days of retention time for each run. For each run, the three digesters were fed with the same mixture of wastes but each digester operates under different operating temperature.

\section{RESULTS AND DISCUSSIONS}

\subsection{Effect of Digestion Temperature}

As stated in most references, operating temperature is considered as one of the most important factors affecting anaerobic digestion. Anaerobic digestion can basically occur under mesophilic mode (32-40 $\left.{ }^{\circ} \mathrm{C}\right)$, thermophilic mode $\left(45-60{ }^{\circ} \mathrm{C}\right)$ or psychrophilic mode $\left(<20^{\circ} \mathrm{C}\right)$. As mentioned previously, this study has been done to investigate the biogas production process under these three possible digestion modes named thermophilic, mesophilic and ambient condition. Thermophilic anaerobic bacteria have some advantages over mesophilic anaerobes because thermophilic species grow at faster rates and some of them are able to degrade polymers such as cellulose and starch by the secretion of cellulolytic enzymes. As a result, better conversion of waste to biogas is achieved. In addition, thermophilic processes have shorter hydraulic retention times due to the high degradation rate. Additionally, sanitation of the digested sludge is achieved due to the reduction in pathogens caused by high temperature [13].
Figure (2) shows the daily biogas yield for the three digesters during the first test run carried out using pure cattle manure during the period from 10/1/2011 to $9 / 2 / 2011$. Each of the three digesters operates under one of the pre-mentioned digestion modes. From the figure it can be noticed that the total biogas yield of thermophilic mode (1292 liter) is higher than that given by mesophilic mode (1243 liter). This result agrees with that obtained by Hammad et al. [7]. The ambient mode of the same run gives lower total biogas yield (362 liter). In addition, the peak value of biogas yield for thermophilic mode (85 liter) occurred four days before the peak value for mesophilic mode (66 liter) that can be attributed to the short of retention time because of the high digestion temperature. Another peak of the daily gas yield is shown for mesophilic mode during the $28^{\text {th }}$ and $29^{\text {th }}$ days which could be reasoned due to the increase in the operating temperature to $50^{\circ} \mathrm{C}$ due to temporal technical fault in the thermostat.

Figure (3) shows the daily biogas yield under the different digestion modes for the second test run, which was carried out within the period from 8/3/2011 to $7 / 4 / 2011$, using cattle manure mixed with rice straw as organic waste. From this figure it can be noticed that thermophilic mode gives the highest total gas yield (2224 liter) followed by mesophilic mode (2089 liter), and the ambient mode comes in the last position (444 liter). Also, these results are consistent with that obtained by Hammad et al. [7] as mentioned above. Moreover, it can be observed that from Fig .3, the daily biogas yield increases gradually for ambient mode at the end of HRT (at day 26). This may be due to the delay in the fermentation process of the used feedstock used mixture, which contains high lignin ratio (8-12\%) under lower temperatures [14] leading to low biodegradability under anaerobic conditions as stated by [13].

The obtained daily biogas yields for the three digesters during the third test run (17/4/2011$17 / 5 / 2011$ ) are given in figure (4). From the figure it

Table 1, The wastes combination ratios for the three test run

\begin{tabular}{|l|l|c|c|c|c|c|}
\hline \multicolumn{2}{|l|}{ Materials } & Cattle manure & Rice straw & Hen manure & Digested sludge & Water \\
\hline \multirow{2}{*}{$\begin{array}{l}\text { Ratio } \\
\%\end{array}(\mathrm{v} / \mathrm{v})$} & Run 1 & 40 & 0 & 0 & 10 & 50 \\
\cline { 2 - 7 } & Run 2 & 30 & 3 & 0 & 10 & 57 \\
\cline { 2 - 7 } & Run 3 & 22 & 0 & 8 & 11 & 59 \\
\hline
\end{tabular}

can be observed that thermophilic mode gives higher yield of biogas (5755 liter) than mesophilic mode (3185 liter). These results have the same trend as the last described above two runs; i.e. the biogas yield in thermophilic mode is always higher than that of mesophilic mode. The biogas yield for the ambient mode for this test run is relatively higher than that for the preceding test runs (2325 liter) which can be ascribed due to the higher ambient temperature ranging between $20^{\circ} \mathrm{C}$ to $37^{\circ} \mathrm{C}$ during the $3^{\text {rd }}$ run. 


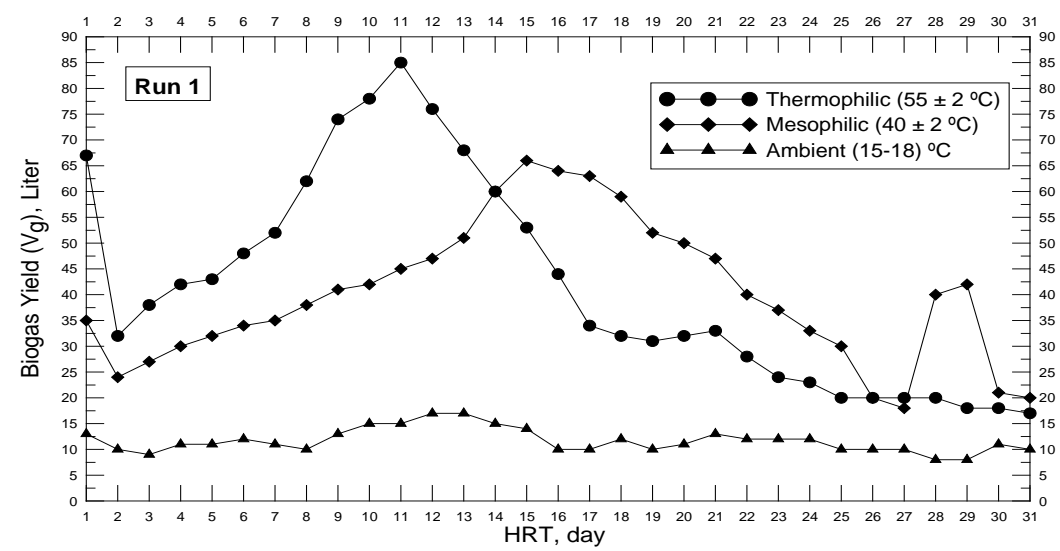

Fig.2 Daily biogas yields in liters at $6 \mathrm{~mm}$ of average head pressure $(\Delta \mathrm{h})$ for different digestion modes during 31 day of HRT for Run 1

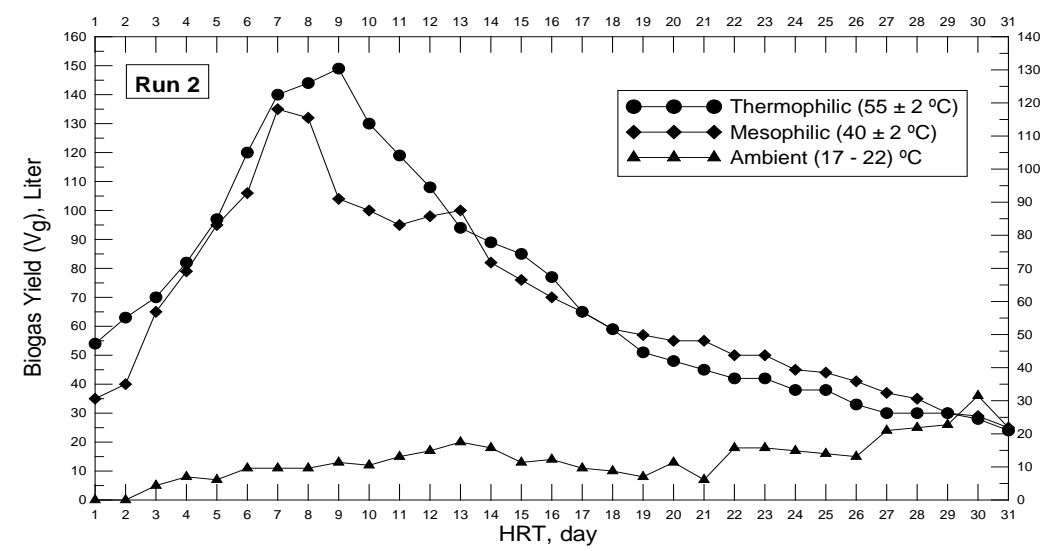

Fig.3 Daily biogas yields in liters at $9 \mathrm{~mm}$ of average head pressure $(\Delta \mathrm{h})$ for different digestion modes during 31 day of HRT for Run 2

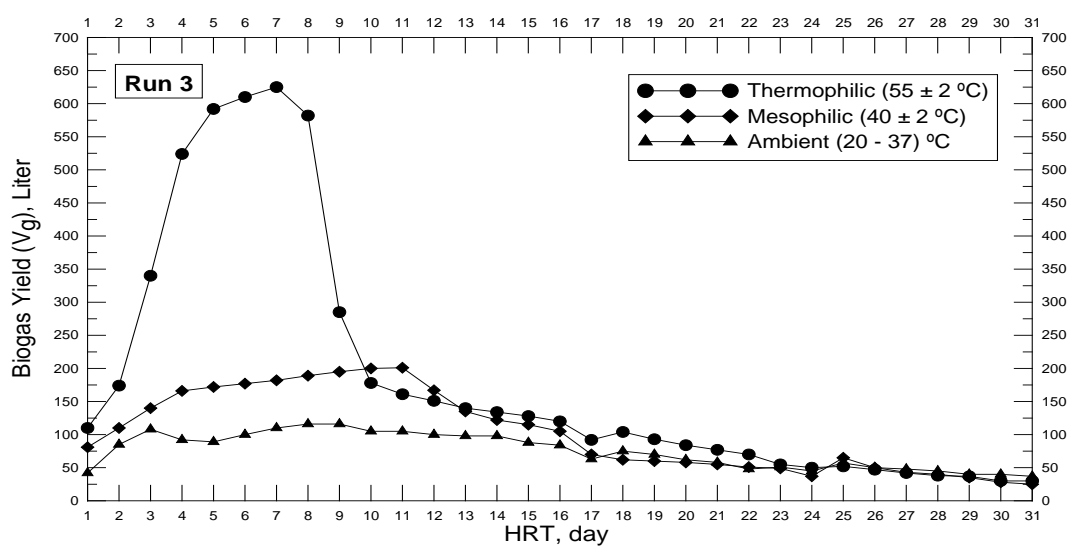

Fig.4 Daily biogas yields in liters at 20mm of average head pressure $(\Delta \mathrm{h})$ for different digestion modes during 31 day of HRT for Run 3

\subsection{PH Value for the Different Digestion Modes}

The allowable $\mathrm{pH}$ value for biogas production is in the range of 6.6 and 7.6. The $\mathrm{pH}$ in the anaerobic digester is a function of the bicarbonate alkalinity of the system, the fraction of $\mathrm{CO}_{2}$ in the digester gas and the concentration of VFA. The $\mathrm{pH}$ may decrease when organic acids are produced during the breakdown of organic materials. When acid forming bacteria and the methanogenic bacteria are present in an equilibrium reaction, the $\mathrm{pH}$ of the entire system will equilibrate at a value of approximately 7 , since the organic acids will be removed as they are produced [15]. Alkalinity plays an important role in 
reactors' stability as its buffer capacity maintains the $\mathrm{pH}$ at appropriate levels. Long chain fatty acids (more than eight carbons), which are the components of natural fats, are strong inhibitors of methanogenesis from acetate [13]. A slightly alkaline mixture is best for digesters using animal manures or plant wastes.

Table (2) gives the measured $\mathrm{pH}$ values for each test run. From this table, it can be observed that all $\mathrm{pH}$ values are almost higher than 7 , which means that all slurries are alkaline due to existence of cattle manure which contain high ammonia concentration but below the inhibition limit (150 mg/L) [13]. As shown in table (2) the thermophilic mode, which gives the highest biogas yield has $\mathrm{pH}$ value more than 8 . This may be due to the increased ammonia generation in thermophilic digestion [8]. For mesophilic and ambient modes $\mathrm{pH}$ values are lower than thermophilic mode due to lower temperatures for each mode of $\left(40 \pm 2{ }^{\circ} \mathrm{C}\right)$ and $(15-37){ }^{\circ} \mathrm{C}$, respectively. Also, it can be observed that, the optimum values of $\mathrm{pH}$ are ranging between (8.1 8.51) for thermophilic mode while its optimum values are ranging between $(7.11-8.24)$ for each of mesophilic and ambient modes.

\subsection{Effect of the Type of Organic Waste}

It is well known that biogas production rates depend on the composition and biodegradability of the feedstock as well as the digestion temperature as mentioned earlier. Carbon to nitrogen ratio $(\mathrm{C} / \mathrm{N})$ is the main parameter widely used to estimate the biodegradability potential of a particular feedstock. Based on biodegradable organic carbon, $\mathrm{C} / \mathrm{N}$ ratio of 20-30 is considered to be optimum for an anaerobic digester [17]. Animal waste, such as cattle manure, has an average $\mathrm{C} / \mathrm{N}$ ratio of 24 . Meanwhile hen manure and rice straw have $\mathrm{C} / \mathrm{N}$ ratios of 10,70 respectively [18]. To maintain the $\mathrm{C} / \mathrm{N}$ level of the digester material at acceptable levels, materials with high $\mathrm{C} / \mathrm{N}$ ratio can be mixed with those with a low $\mathrm{C} / \mathrm{N}$ ratio. The TS content for the used input slurry varies with the type of manure, handling system and mixing ratio. Hen manure has $(10-30 \%)$ TS while, TS for cattle manure ranges between $5-12 \%$ depending on dilution [16]. Some bedding materials like rice straw (high lignin content) are very resistant to degradation and may require pre-treatment to enhance degradability [15] and therefore; a pretreatment was performed for the used rice straw in the second run by placing it in water for one week before feeding to ease the fermentation process. Table (3) shows the sample compositions and its initial total solid content \%TS for each test run. The daily biogas yields for each digestion mode of the three test run are illustrated in the figures $(5,6$ and 7). These figures give the effect of feedstock type on the biogas yield for each digestion mode.

Table 2, Measured $\mathrm{pH}$ values with respect to peak value of biogas yield for each digestion mode through each test run

\begin{tabular}{|c|c|c|c|c|}
\hline & & & \multirow{3}{*}{$\begin{array}{c}\text { At Peak Value } \\
8.1\end{array}$} & \multirow{3}{*}{$\begin{array}{c}\text { After Peak Value } \\
8.12-8.33 \\
\end{array}$} \\
\hline \multicolumn{2}{|c|}{ Test Runs } & \multirow{2}{*}{$\begin{array}{c}\text { Before Peak Value } \\
7.4-8\end{array}$} & & \\
\hline \multirow{3}{*}{ Run 1} & Thermophilic & & & \\
\hline & Mesophilic & $7.5-7.62$ & 7.5 & $7.76-8.36$ \\
\hline & Ambient $\left(15-18^{\circ} \mathrm{C}\right)$ & $7.58-7.7$ & 7.11 & $7.7-7.92$ \\
\hline \multirow{3}{*}{ Run 2} & Thermophilic & $7.1-8.4$ & 8.51 & $8.21-8.64$ \\
\hline & Mesophilic & $7.2-7.41$ & 7.92 & $8-8.32$ \\
\hline & Ambient $\left(17-22^{\circ} \mathrm{C}\right)$ & $7.2-7.88$ & 7.48 & 7.42 \\
\hline \multirow{3}{*}{ Run 3} & Thermophilic & $7.12-8.12$ & 8.24 & $8.26-8.51$ \\
\hline & Mesophilic & $6.91-8.13$ & 8.24 & $8.4-8.69$ \\
\hline & Ambient $\left(20-37^{\circ} \mathrm{C}\right)$ & $7.2-7.5$ & 7.63 & $7.77-8.08$ \\
\hline
\end{tabular}

Table 3, Samples compositions and its total solid content for each test run

\begin{tabular}{|l|c|c|c|c|c|c|}
\hline & ITS \% & Cattle manure & Rice straw & Hen manure & Digested sludge & Water \\
\hline Run 1 & 24.44 & 40 & 0 & 0 & 10 & 50 \\
\hline Run 2 & 7.34 & 30 & 3 & 0 & 10 & 57 \\
\hline Run 3 & 9.4 & 22 & 0 & 8 & 11 & 59 \\
\hline
\end{tabular}

From these figures, it can be noticed that the third test run gives higher daily biogas yield for all digestion modes meanwhile; the first run comes at the last stage. It is stated that, the optimum value of the total solid content of the input slurry ranges between 8 to 10\% [19]. Based on this statement, it could be concluded that the main reason that the third test run gives the highest biogas yield at its initial \%TS value $(9.4 \%)$ located within the optimum range. There is another reason for the increased biogas yield in the third test run; is to the co-digestion for the input slurries as the use of a co-substrate improves biogas yield due to the supply of essential nutrients 
by the co-substrates, which reduces process inhibition and enhances biodegradability [20].

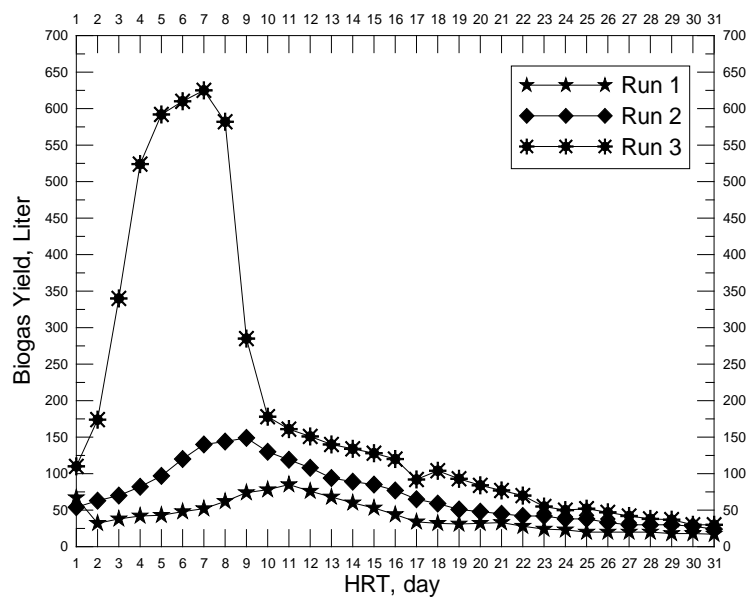

Fig.5 Biogas yields in liters at thermophilic condition $\left(55 \pm 2{ }^{\circ} \mathrm{C}\right)$ for each test run

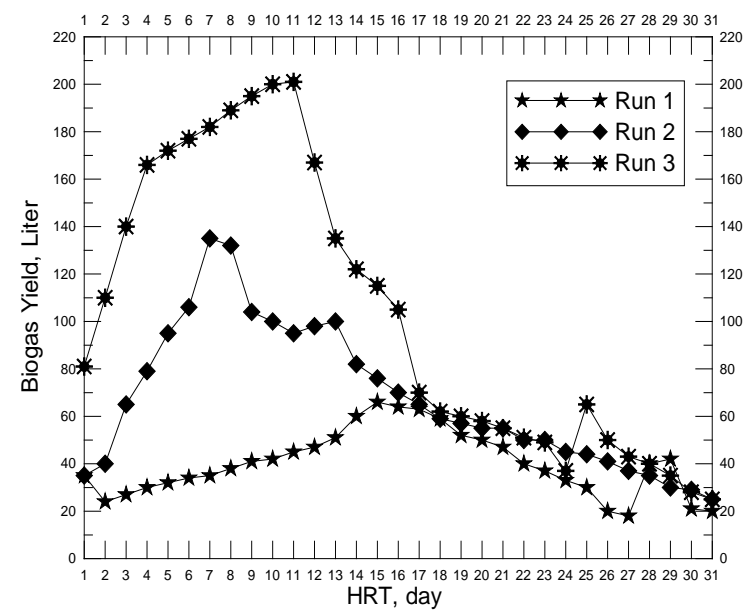

Fig.6 Biogas yields in liters at mesophilic condition $\left(40 \pm 2{ }^{\circ} \mathrm{C}\right)$ for each test run

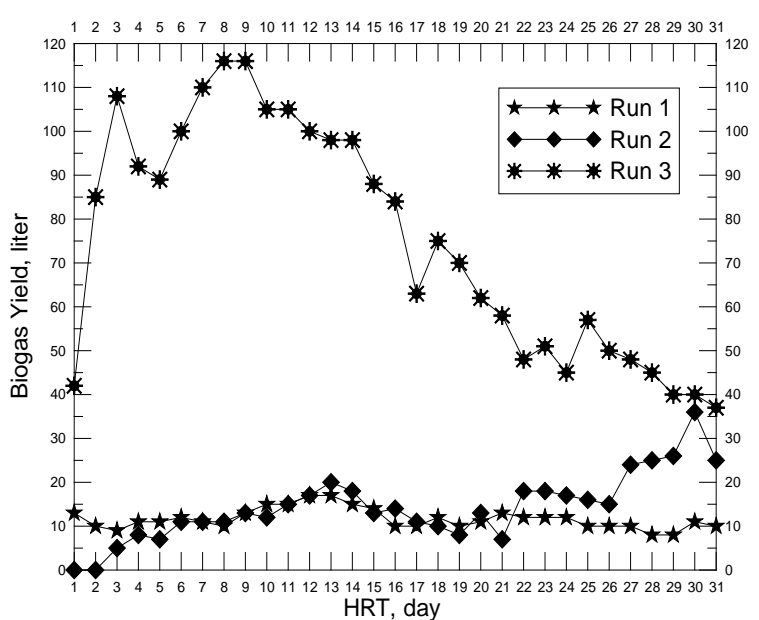

Fig.7 Biogas yields in liters at ambient condition $\left(15-37^{\circ} \mathrm{C}\right)$ for each test run

\section{CONCLUSIONS}

Biogas production from organic wastes could be enhanced by controlling the operating conditions such as temperature and the type of organic waste in its optimum values. The following statements could be concluded from the current study:

1. Thermophilic mode gives the best biogas yield for the used organic wastes.

2. Thermophilic mode is more suitable for anaerobic digestion of the high solid organic wastes than mesophilic mode although thermophilic mode leads to increaseing $\mathrm{pH}$ values due to higher ammonia content.

3. The optimum value of $\mathrm{pH}$ is about 8.24 for thermophilic mode while it is about 7.92 for mesophilic mode.

4. The co-digestion and mixing substrates can lead to higher biogas yield.

5. Total solid content is an important factor for anaerobic digestion.

6. Adding digested sludge can accelerate the anaerobic reaction and enhance the biogas yield.

\section{Nomenclature}

COD chemical oxygen demand (mg/l)

HRT hydraulic retention time (day)

ITS initial total solid (\%)

OTS organic total solid (kg)

$\mathrm{T}_{\text {op }} \quad$ operating temperature $\left({ }^{\circ} \mathrm{C}\right)$

$\mathrm{T}_{\mathrm{amb}}$ ambient temperature $\left({ }^{\circ} \mathrm{C}\right)$

TS total solids (\%)

$\mathrm{v} / \mathrm{v}$ the percentage of waste volume in the total slurry (\%)

$\mathrm{V} \quad$ volume (liter)

VFA volatile fatty acids (mg/l)

VS volatile solid (gm)

$\Delta \mathrm{h}$ pressure head $(\mathrm{mm})$

Abbreviations

$\mathrm{AD} \quad$ Anaerobic Digestion

$\mathrm{C} / \mathrm{N} \quad$ Carbon to Nitrogen ratio

COD Chemical Oxygen Demand

MSW Municipal Solid Waste

OFMSW Organic fraction of municipal solid waste $\mathrm{pH} \quad$ Acidity degree value

\section{REFERENCES}

[1] http://www.alasdiqaa.com/as/index.php?option= com_content\&view=article\&id=914:-11-4011\&catid=48:2010-03-31-11-19-57\&Itemid =88, accessed May, 2011.

[2] http://www.fao.org/ag/againfo/programmes/es/le ad/toolbox/Tech/EL_S0291.pdf, accessed April, 2010.

[3] B. Sarapatka, "Factors Influencing Biogas Production during Full-Scale Anaerobic 
[4] Fermentation of Farmyard Manure", Bioresource Technology, Vol. 49, 1994, pp. 17-23.

[5] A. K. Kalia and S. S. Kanwar, "Long-Term Evaluation of A Fixed Dome Janata Biogas Plant in Hilly Conditions", Bioresource Technology, Vol. 65, (1998), pp. 61-63.

[6] Anjan K. Kalia and Shiv P. Singh, "Case study of $85 \mathrm{~m}^{3}$ floating drum biogas plant under hilly conditions", Energy Conversion \& Management,Vol. 40, (1999), pp. 693-702.

[7] Franco Cecchi, Paolo Pavan, Joan Mata Alvarez, Angelo Bassetti and Ciro Cozzolino, "Anaerobic digestion of municipal solid waste: Thermophilic vs. mesophilic performance at high solids", Waste Management \& Research, Vol. 9, 1991, pp. 305-315.

[8] M. Hammad, D. Badarneh and K. Tahboub, "Evaluating variable organic waste to produce methane", Energy Conversion \& Management, Vol. 40, (1999), pp. 1463- 1475.

[9] Anette Hejnfelt and Irini Angelidaki. "Anaerobic digestion of slaughterhouse by-products". Biomass and bioenergy, Vol. 33, (2009), pp. 1046 - 1054.

[10] M.R. Al-Masri, "Changes in biogas production due to different ratios of some animal and agricultural wastes", Bioresource Technology, Vol. 77, (2001), pp. 97-100.

[11]E. O. Uzodinma, A. U. Ofoefule J. I. Eze, I. Mbaeyi and N. D. Onwuka. "Effect of some organic wastes on the biogas yield from carbonated soft drink sludge". Scientific Research and Essay, Vol. 3(9), 2008, pp. 401405.

[12] Uzodinma, E.O. and Ofoefule, A.U. "Biogas production from blends of field grass (Panicum maximum) with some animal wastes". International Journal of Physical Sciences, Vol. 4(2), pp. 091-095, 2009.

[13] G. Lastella, C. Testa, G. Cornacchia, M. Notornicola, F. Voltasio and Vinod Kumar Sharma, "Anaerobic digestion of semi-solid organic waste: biogas production and its purification". Energy Conversion and Management, Vol. 43, (2002), pp. 63-75.

[14] Maritza Argelia Macias-Corral, "Biogas Production via Anaerobic Digestion of HighSolids Livestock Manure", PhD thesis, Las Cruces, New Mexico, May 2007.

[15] http://jenkins.ucdavis.edu/projects/RiceStraw/Ri ceStrawDocs/SummersESPM286FinalReport.pd f, accessed June, 2011.

[16] Tanya McDonald, "Co-digestion of Agricultural, Municipal and Agro-industrial Wastes in Rural Communities", Master Thesis, CALGARY, ALBERTA, September, 2007.

[17] Steffen, R.; Szolar, O. and Braun, R., "Feedstocks for anaerobic digestion" Institute for Agrobiotechnology Tulln, University of Agricultural Sciences Vienna, 1998, http://www.adnett.org/dl_feedstocks.pdf, accessed June, 2011.

[18]L. John Fry, "Methane Digesters for Fuel Gas and Fertilizer with Complete Instructions for Two Working Models", available at website: http://journeytoforever.org/biofuel_library/Meth aneDigesters/MDToC.html, accessed April, 2010.

[19] Food and Agriculture Organization of the United Nations," Biogas Technology: A Training Manual for Extension", NEPAL, September 1996, Available at website: http://www.scribd.com/doc/38806885/null, accessed April, 2010.

[20] M.A. Sathianathan, "BIO-GAS Achievements \& Challenges" book, Association of Voluntary Agencies for Rural Development, New Delhi 110048.

[21] J. Mata-Alvarez, S. Mace and P. Llabres, "Anaerobic digestion of organic solid wastes. An overview of research achievements and perspectives", Bioresource Technology, Vol. 74, (2000), pp. 3-16. 